\title{
UTILIZATION OF ENSILED METABOLIZABLE MIXTURE OF CASSAVA PEEL AND CAGED LAYERS' MANURE AS ENERGY SOURCE IN BROILER DIETS
}

\section{Dairo FAS ${ }^{1 *}$}

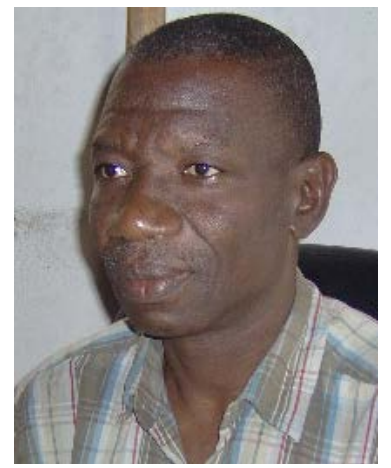

Ayodeji Dairo

Corresponding author email: fasdairo@yahoo.com

${ }^{1}$ Department of Animal Production and Health Sciences, Faculty of Agricultural Sciences, University of Ado-Ekiti, P.M.B. 5363, Ado-Ekiti, Ekiti State, Nigeria. 


\section{ABSTRACT}

An experiment was carried out in which dried cassava peel and dried caged layers' manure mixed in ratio 5:1 (w/w) was ensiled for 14 days and the mixture used to partially replace maize, an expensive energy source in broiler diets in most developing countries at $0 \%, 25 \%$ and $50 \%$ dietary inclusion levels. The response of the birds to the different dietary inclusion of fermented mixture of cassava peel and caged layers' manure (FCPCLM) as it affected performance, carcass cut-parts, serum proteins and enzymes was monitored in a completely randomized design trial. The study also evaluated the cost of feed and the suitability of FCPCLM as an alternative unconventional source of energy in broiler starter diet. A total of 90 day old chicks of Anark breed were divided into three groups containing three replicates each. There were ten birds per replicate. Each group of birds were fed each of the dietary treatment ad libitum for 56 days, divided into starter phase (0 to 28 days) and finisher phase (29 to 56 days). Feed intake, body weight gain, feed conversion ratio (FCR) protein efficiency ratio (PER), total protein, albumin, globulin, aspartate amino transaminase (EC 2.6.1.1.1), alanine amino transaminase (EC 2.6.1.1.2) and carcass cut parts were determined. Results showed linear increase $(\mathrm{p}<0.05)$ in feed intake, live weight, body weight gain, FCR, and PER for all the phases during the experiment. The serum proteins and enzymes were not $(p>0.05)$ influenced by treatments. The eviscerated weight, wings, breast and large intestine length were higher $(p<0.05)$ in birds fed 50\% replacement of maize by FCPCLM. The cost of feed per kilogramme and cost per kilogramme flesh gained was lowest and best $(\mathrm{p}<0.05)$ in broilers chicks fed 50\% replacement of maize by FCPCLM. Therefore, FCPCLM in broiler starter diet at 50\% dietary level support good performance, enhanced gain in eviscerated weight and reasonable cost per kilogramme gain without any noticeable effect on the serum indices and enzymes hence can be recommended for use by poultry farmers on subsistence production.

Key words: Fermentation, performance, carcass, cost, feed 


\section{INTRODUCTION}

Feed is an important component of poultry enterprise and has been generally known to be responsible for between 70 to $80 \%$ of the total cost of production. Cost of energy in poultry feed had been reported to be about $70 \%$ of the total feed cost and about $40 \%$ of poultry production cost [1,2]. Some of the feed raw materials used in poultry feed production such as the cereals, oil seed cakes and other agro-industrial by-products are still being largely imported at high cost to keep the poultry and livestock industries going in many developing countries. Maize is the main source of energy in most farm animal feeds. In the developed nations of the world, maize is produced largely to feed livestock. However, the situation is different in the developing countries where cereals, legumes and some other animal feed components constitute staple foods for man. This brings about a "food-feed" competition for these commodities; hence they become expensive component of animal feeds. Alternatives have been researched into as substitute for cereals in livestock feeds such as cassava tuber products and other agro-industrial by-products like wheat bran, maize middling and maize duzza with a view to reduce cost of production $[3,4,5]$.

Recent development where cereals and other carbohydrates sources such as cassava tubers are now being used for ethanol and bio-fuel production has further aggravated the feed situation in many developing countries including Nigeria. Taking cognizance of this situation, a practical and sustainable alternative substitute to maize becomes imperative to stem the over-dependence on expensive imported cereals and industrially manufactured enzymes used as additives in poultry and livestock feeds.

Cassava peels is one of the farm by-products considered as waste from the processing of cassava either into starch, cassava flour or "garri."'[6]. It is readily available and mostly fed to small ruminants. However, its use in poultry diets has been reported [6, 7]. The protein content of cassava peel is very low and is of high fibre content $[3,5]$ therefore cannot be utilized directly by monogastric animals without processing. Poultry manure is noted for its use as fertilizer on crop farms. Also its use as component of farm animal feed has been documented $[8,9]$.

Therefore, this investigation was carried out to study the response of broiler chicken to fermented mixture of cassava peel and caged layers' manure (obtained as farm residue or waste) and fed as a component of energy source in the feed.

\section{MATERIALS AND METHODS}

\section{Collection and preparation of experimental test material}

Fresh cassava peel was collected from the cassava processing shed of the University Teaching and Research Farm, sun dried to crispy touch and milled in a commercial feed milling machine (Artec, model 20) with $3 \mathrm{~mm}$ sieve. It was bagged and kept for fermentation process.

Polythene sheet was spread under battery cages that housed laying birds in the Poultry Unit of the University of Ado-Ekiti Teaching and Research Farm to collect the 
manure on daily basis for three days. Feathers, broken eggs, egg shell, and other impurities were manually removed from the wet manure, sun dried, grounded in Christy and Norris laboratory mill and bagged for fermentation. Rumen contents of freshly slaughtered and disembowelled bovine were collected from one of the abattoirs in the town. The liquid was squeezed out of the rumen contents by manual pressing and filtered into a four litre jar using muslin cloth.

\section{Fermentation procedure and preparation of experimental diets}

Twenty-five kilogramme of ground cassava peel and five kilogramme of dried and milled caged layers' manure were mixed (which is ratio $5: 1 \mathrm{w} / \mathrm{w}$ ). This ratio was obtained by using the analyzed crude protein (Table 1) values of FCPCLM $(6.19 \pm 0.0$ $\% \mathrm{CP})$ and that of the caged layers' manure $(24.0 \pm 0.2 \% \mathrm{CP})$ to formulate a mixture that would have $9 \% \mathrm{CP}$ which is the value found in maize using the Pearson square method. The mixture was slightly moistened with one litre of water, sprayed with 100 $\mathrm{ml}$ of rumen filtrate for every five kilogramme part and then re-mixed on the floor using plastic scoop. The moistening with water and eventual air-tight environment enhanced microbial multiplication and fermentation. The final mix was divided into three equal parts and poured separately into three different 50 litre vats with black polythene bag in each. The content was pressed, tied tightly and again covered with black polythene sheet to facilitate fermentation. The three vats were marked separately to ferment for a period of 7, 14 and 21 days respectively. This was done to determine the effects of period of fermentation on the nutrient upgrade in the test ingredients. Unpublished preliminary investigations by the authors indicated no significant difference in the proximate composition of the fermented cassava peel and dried caged layers' manure (FCPCLM) at 14 and 21 days while it was lowest in the seven day period. Hence the former was used as replacement for maize without further testing for longer period of fermentation. The lumps of FCPCLM were broken and thoroughly mixed. It was used to partially replace maize in a pre-formulated broiler starter diet at 25\% and 50\% dietary levels with a control.

\section{Data collection}

Feed intake (FI) and body weight gain (BWG) were measured on weekly basis and later converted to daily values by dividing by seven. Feed conversion ratio (FCR), protein intake and protein efficiency ratio (PER) were calculated from FI and BWG. Feed conversion ratio was calculated as feed to gain ratio while PER was obtained as gain in weight to protein intake. Data collection was done for the first 28 days of age (starter phase, 0 to 4 weeks), the last 28 days (finisher phase, 5 to 8 weeks) and for 0 to 56 days that the feeding trial lasted. On the $56^{\text {th }}$ day, three birds from each of the replicates were sacrificed by decapitation and processed for carcass evaluation. About $5 \mathrm{ml}$ of the blood sample for each replicate was taken and allowed to clot at ambient temperature of about $26^{\circ} \mathrm{C}$. The serum for each replicate was separated by centrifugation at 2500 revolution per min in a bench top Harris centrifuge (model $\mathrm{C} 2474 / 2$ ), stored in a refrigerator at $4^{\circ} \mathrm{C}$ and later analyzed for total protein, albumin, globulin, aspartate amino transaminase (AST) (EC 2.6.1.1.1) and alanine amino transaminase (ALT) (EC 2.6.1.1.2). 


\section{Chemical analysis}

Proximate composition of cassava peel meal, poultry manure, fermented cassava peel and dried caged layer manure and the experimental diets were carried out as described by AOAC [10]. Three determinations were carried out and the mean calculated for each parameter. Essential amino acid content of FCPCLM and maize was determined using amino acid analyzer (model 80-2107 Auto Loader). The metabolizable energy (ME) of FCPCLM was calculated using the prediction equation M. E. = $37 \mathrm{x} \%$ CP + $81.8 \times \%$ EE $+35.5 \times$ \% NFE [11]. Serum total protein was assayed by the biuret method, albumin by Doumas and Briggs and globulin by Rodkey [12, 13, 14]. The method described by Reitman and Frankel was adopted for aspartate aminotransferase (AST) and alanine amino transferase (ALT) determined using Bausch and Lamb spectrophotometer [15].

\section{Microbial screening of test ingredient}

The fermented mixture of cassava peel and dried caged layers' manure was screened for Salmonella, Clostridium and enterobacteria because of their health importance in poultry and human by the modification of the methods of Fawole and Oso [16]. Enterobacterium was determined using desoxycholate citrate agar lactose (DCL) while Salmonella-Schigella agar was used for Salmonella. They were both incubated at $37^{\circ} \mathrm{C}$ for $24 \mathrm{~h}$. Plate count agar was used to obtain the standard plate count. It was incubated for $72 \mathrm{~h}$ at $30{ }^{\circ} \mathrm{C}$. Clostridium was determined after its heat activation at about $80{ }^{\circ} \mathrm{C}$ incubated on Clostridium agar at $30{ }^{\circ} \mathrm{C}$ for $48 \mathrm{~h}$.

\section{Statistical analysis}

All the data collected for performance, serum chemistry and enzyme activity were subjected to statistical analysis using GLM procedure of type III for ANOVA and ttest of SAS software [17].

\section{RESULTS}

Proximate composition of fermented mixture of cassava peel and dried caged layers' manure (FCPCLM) is shown in Table 1. The crude protein content of FCPCLM was superior to that of cassava peel but lower than that of poultry manure. The fat and nitrogen free extract contents were lower in FCPCLM than for maize. The ash value was highest in caged layer manure while FCPCLM and maize have similar values and cassava the lowest. Metabolizable energy of maize and FCPCLM were similar and higher than cassava peel and caged layer manure. Table 3 shows the microbial load of enterobacteria, Salmonella and Clostridium found in FCPCLM. Some essential amino acids (Table 4) namely lysine, valine, histidine, phenylalanine and arginine have higher values in FCPCLM than maize while the total essential amino acid was higher in maize.

Table 5 shows the performance data for the different phases of this study. Inclusion of FCPCLM in the broiler starter diet had linear significant ( $>0.05$ ) effect on the feed intake, body weight gain and live weight at 28 days of age with birds on $50 \%$ FCPCLM recording the highest values (71.50 g, 37.41g and $1036 \mathrm{~g}$ ) while the feed conversion ratio (FCR) decreased linearly $(\mathrm{p}<0.05)$ in the control group (1.89). The 
cost per kg flesh gained was best for birds fed 50 \% FCPCLM ( $\$ 160.04)$ The protein efficiency ratio of the broiler starter chicks was not affected by the treatment ( $>0.05$ ). The control diet had the highest feed cost per kilogramme (\$92.9) while experimental diet with 50\% inclusion of FCPCLM was lowest (\$82.9). These values followed the same trend for nearly all the parameters at the finisher phase and 0 to 56 days of the study (Table 5). The exchange rate as at the time of this trial was 1 US\$ = N 145 .

Serum values for total protein, albumin, globulin and the enzymes activities (AST and ALT) were not significantly $(\mathrm{p}<0.05)$ affected by the inclusion of FCPCLM in the broiler diets (Table 6).

The carcass characteristics and cut parts (Table 7) showed that eviscerated weight, wings, breast and the large intestine values were similar in birds fed $25 \%$ and $50 \%$ replacement of maize but higher $(p<0.05)$ than the control. All other cut parts were not affected ( $>00.05$ ) by the dietary inclusion of FCPCLM.

\section{DISCUSSION}

The values of nutrients (especially crude protein) in FCPCLM improved considerably after fermentation. Rumen microbes have the ability to synthesize enzymes such as $\beta$-glucanase that can digest cellulose and hemicellulose which constitutes the component of cassava peel and other fibrous feed materials [18]. The nitrogenous component and the non-protein nitrogen hitherto locked up within the cell as a result of the cellulose and or hemicellulose of the wall components became available in the test ingredient after cellolytic action of the microbes. This explains the increase in the crude protein content of the fermented mixture [19, 20]. In addition, the microbes which are proteinous also contributed (as single cell proteins) to the overall protein concentration of FCPCLM. From this study, the crude protein content of FCPCLM $(8.71 \pm 0.78 \%)$ almost equate with that of maize $(9.69 \pm 0.81 \%)$ as obtained in this study (Table 1). The crude fibre also decreased in FCPCLM as a result of the fermentation when compared with the values obtained for cassava peel (Table 1). Metabolizable content of FCPCLM was calculated to be $3157 \mathrm{kcal} / \mathrm{kg}$ which compared favourably with that of maize (3637 kcal/kg) obtained by using Pauzenga equation [11]. Some essential amino acids namely lysine, valine, histidine, phenylalanine and arginine have higher values in FCPCLM than maize (Table 4) which was a result of the microbial content of the fermented ingredients.

The feed intake increased linearly with increase in dietary inclusion of FCPCLM and consequently a corresponding effect on the body weight gain and live weight gain. This effect was also observed in the values of FCR and PER. This trend was the same for the starter and finisher phases and through out the experimental period. The FI in this study was at variance with the report of Osei, but there was agreement with his findings on body weight gain [7,21]. The increase in body weight of the birds as FCPCLM partially replaced maize indicated an improvement in the utilization of the diets. Birds fed diets with $50 \%$ partial replacement of maize had superior live weight, body weight gain and feed conversion ratio for the $0-28$ days, and $29-56$ days. The 
treatment effect on these parameters also manifested when considered over the 56 day feeding trial.

Eviscerated weight of birds fed 50\% FCPCLM replacement of maize increased by $5.62 \%$ over the control group while those on $25 \%$ FCPCLM was also higher by $1.86 \%$. The wings of broiler birds fed diets with 50\% FCPCLM was higher by 17.03 $\%$ than while the breast also increased by $11.76 \%$ over the control group. Experimental birds on $50 \%$ FCPCLM appeared to utilize the feed better than the control which might be as a result of the improved content and possible availability of the essential amino acids in the feed.

The values obtained for the microbial count when FCPCLM was screened indicated that the fermented product was safe to use as feed component in poultry feed. The microbial load is low because of the fermentation process that must have made the environment acidic (even though the exact $\mathrm{pH}$ value was determined) hence not very conducive for their growth $[18,19]$. Fermented cassava peel and caged layers' manure is promising and unique for use by farmers who do not have access to industrial microbial enzymes extract like xylannase and glucanase. This procedure will no doubt help subsistent farmers in the very rural setting where a measure of integrated farming is practiced. The raw materials are readily available on the farm and can be easily carried out using locally adapted and non sophisticated facilities.

\section{CONCLUSION}

In the present situation where cereals and tubers which are the main carbohydrate sources in livestock and broiler chicken feeds are effectively used for bio-fuel production, a serious gap is gradually being created in the supply of cereals for poultry and livestock feeds. The use of fermented mixture of cassava peels and dried caged layers' manure in partial replacement of maize may go a long way in reducing the cost of energy source and the sustainability of poultry farmers especially at subsistence level. However, the microbial load of the poultry manure must be ascertained for safety as this may differ based on the biosecurity of the farm environment. 
Table 1: Proximate composition and metabolizable energy values of fermented mixture of cassava peel and caged layer manure, cassava peel, caged layer manure and maize (\%)

\begin{tabular}{|c|c|c|c|c|}
\hline \multirow[t]{3}{*}{ Parameters } & 『FCPCLM & Maize & Cassava & Caged Layer \\
\hline & Mean \pm SD & Mean \pm SD & Peel & Manure \\
\hline & & & Mean \pm SD & Mean \pm SD \\
\hline \multirow[t]{2}{*}{ Crude Protein } & $8.71^{b}$ & $9.69^{b}$ & $6.19^{c}$ & $24.0^{\mathrm{a}}$ \\
\hline & \pm 0.1 & \pm 0.11 & \pm 0.0 & \pm 0.2 \\
\hline \multirow[t]{2}{*}{ Crude Fibre } & $11.6^{\mathrm{b}}$ & $1.36^{\mathrm{C}}$ & $18.9^{\mathrm{a}}$ & $16.2^{b}$ \\
\hline & \pm 0.02 & \pm 0.01 & \pm 0.12 & \pm 0.1 \\
\hline \multirow[t]{2}{*}{ Fat } & $2.75^{b}$ & $4.07^{\mathrm{a}}$ & $1.18^{\mathrm{C}}$ & $2.35^{b}$ \\
\hline & \pm 0.0 & \pm 0.02 & \pm 0.01 & \pm 0.0 \\
\hline Nitrogen & $73.5^{\mathrm{a}}$ & $82.9^{\mathrm{a}}$ & $66.6^{\mathrm{b}}$ & $38.8^{\mathrm{c}}$ \\
\hline Extract & \pm 0.2 & \pm 0.12 & \pm 0.25 & \pm 0.3 \\
\hline \multirow[t]{2}{*}{ Ash } & $3.97^{\mathrm{c}}$ & $3.68^{\mathrm{c}}$ & $6.01^{b}$ & $18.6^{\mathrm{a}}$ \\
\hline & \pm 0.1 & \pm 0.0 & \pm 0.21 & \pm 0.01 \\
\hline Metabolizable & $3157^{\mathrm{a}}$ & $3637^{\mathrm{a}}$ & $2686^{b}$ & ND \\
\hline $\begin{array}{l}\text { Energy } \\
\text { (Kcal/kg) }\end{array}$ & \pm 0.5 & \pm 0.21 & \pm 0.71 & \\
\hline
\end{tabular}

Means with different superscript differ significantly $(\mathrm{p}<00.05)$ FCPCLM = Fermented mixture of cassava peel and caged layers' manure Values are mean of three determinations \pm SD; SD = Standard deviation 


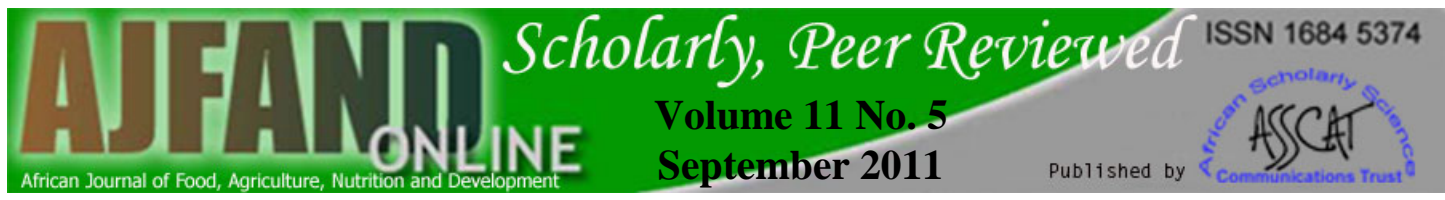

Table 2: Composition of experimental diets (\%)

\begin{tabular}{|c|c|c|c|c|c|c|}
\hline \multicolumn{4}{|c|}{$\begin{array}{c}\text { STARTER PHASE } \\
\% \text { replacement of maize with FCPCLM }\end{array}$} & \multicolumn{3}{|c|}{$\begin{array}{c}\text { FINISHER PHASE } \\
\% \text { replacement of maize with FCPCLM }\end{array}$} \\
\hline Ingredients & 0 & 25 & 50 & 0 & 25 & 50 \\
\hline Maize & 40.00 & 30.00 & 20.00 & 45.00 & 40.00 & 35.00 \\
\hline Wheat offal & 19.00 & 19.00 & 19.00 & 20.00 & 20.00 & 20.00 \\
\hline $\begin{array}{l}\text { Groundnut } \\
\text { cake }\end{array}$ & 12.00 & 12.00 & 12.00 & 12.00 & 12.00 & 12.00 \\
\hline Soybean & 23.00 & 23.00 & 23.00 & 13.00 & 13.00 & 13.00 \\
\hline Fish meal & 1.20 & 1.20 & 1.20 & - & - & - \\
\hline $\begin{array}{l}\text { Palm kernel } \\
\text { meal }\end{array}$ & - & - & - & 5.20 & 5.20 & 5.20 \\
\hline Bone meal & 2.00 & 2.00 & 2.00 & 2.00 & 2.00 & 2.00 \\
\hline Oyster shell & 2.00 & 2.00 & 2.00 & 2.00 & 2.00 & 2.00 \\
\hline *Premix & 0.25 & 0.25 & 0.25 & 0.25 & 0.25 & 0.25 \\
\hline Salt & 0.25 & 0.25 & 0.25 & 0.25 & 0.25 & 0.25 \\
\hline Methionine & 0.10 & 0.10 & 0.10 & 0.10 & 0.10 & 0.10 \\
\hline Lysine & 0.10 & 0.10 & 0.10 & 0.10 & 0.10 & 0.10 \\
\hline $\begin{array}{l}\text { Feed } \\
\text { antibiotic }\end{array}$ & 0.10 & 0.10 & 0.10 & 0.10 & 0.10 & 0.10 \\
\hline \multirow[t]{2}{*}{ ףFCPCLM } & - & 10.00 & 20.00 & - & 10.00 & 20.00 \\
\hline & 100.00 & 100.00 & 100.00 & 100.00 & 100.00 & 100.00 \\
\hline \multicolumn{7}{|c|}{ Determined Analysis (\%) } \\
\hline $\begin{array}{l}\text { Crude } \\
\text { Protein } \\
\end{array}$ & 21.86 & 21.43 & 21.07 & 19.96 & 19.63 & 19.55 \\
\hline Fat & 2.44 & 2.07 & 2.13 & 2.32 & 2.48 & 2.58 \\
\hline Crude Fibre & 4.82 & 6.09 & 6.84 & 5.31 & 6.75 & 8.45 \\
\hline $\mathrm{Ca}$ & 1.53 & 1.55 & 1.57 & 1.45 & 1.34 & 1.52 \\
\hline $\mathrm{P}$ & 0.50 & 0.54 & 0.53 & 0.61 & 0.58 & 0.66 \\
\hline $\mathrm{ME}(\mathrm{MJ} / \mathrm{Kg})$ & 11.66 & 11.55 & 11.42 & 10.94 & 10.87 & 10.79 \\
\hline
\end{tabular}

*Premix supplied the following per kg diet: Vit. A 1x107 ; Mn 80 g;Vit. K 2,250 mg, Fe 20 g; Thiamine 1,750 mg; Cu 5 g; Riboflavin 5,000 mg; Iodine 1.2 g; Pyridoxine 2,750 mg; Se 200 mg; Niacin 2,750 mg; Co 200 mg; Pantothenic acid 7,500 mg; Zn $50 \mathrm{~g}$; Folic acid 7, $500 \mathrm{mg}$.

9 FCPCLM = Fermented mixture of cassava peel and caged layers' manure 


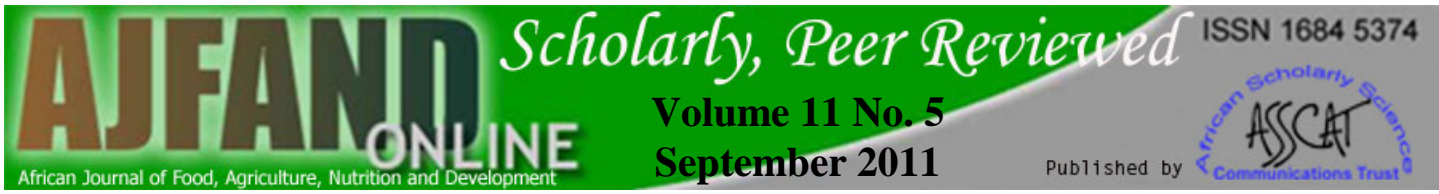

Table 3: Enterobacteria, Salmonella and Clostridium load of fermented mixtures of cassava peel and caged layers' manure used to partially replace maize in broiler starter experimental diets

\begin{tabular}{|l|l|}
\hline Microbes & Concentration $(\mathrm{cfu} / \mathrm{g})$ \\
\hline Enterobacteria & $6 \times 10^{3}$ \\
\hline Salmonella & $\mathrm{ND}$ \\
\hline Clostridium & $3.78 \times 10^{3}$ \\
\hline
\end{tabular}

$\mathrm{ND}=$ Not detected

Table 4: Essential amino acid composition of fermented mixture of cassava peel and caged layers manure and maize $(\%)$

\begin{tabular}{|l|l|l|l|}
\hline Amino acid & FCPCLM & Maize & P- value \\
\hline Lysine & $1.66 \pm 0.02^{\mathrm{a}}$ & $1.24 \pm 0.02^{\mathrm{b}}$ & 0.0001 \\
\hline Methionine & $0.78 \pm 0.01^{\mathrm{b}}$ & $1.48 \pm 0.03^{\mathrm{a}}$ & 0.0001 \\
\hline Valine & $3.64 \pm 0.02^{\mathrm{a}}$ & $2.96 \pm 0.06^{\mathrm{b}}$ & 0.0001 \\
\hline Histidine & $1.64 \pm 0.02^{\mathrm{a}}$ & $1.50 \pm 0.01^{\mathrm{b}}$ & 0.0004 \\
\hline Leucine & $5.11 \pm 0.11^{\mathrm{b}}$ & $8.91 \pm 0.06^{\mathrm{a}}$ & 0.0001 \\
\hline Threonine & $2.13 \pm 0.01^{\mathrm{b}}$ & $2.24 \pm 0.01^{\mathrm{a}}$ & 0.0002 \\
\hline Phenylalanine & $3.17 \pm 0.02^{\mathrm{a}}$ & $3.11 \pm 0.01^{\mathrm{b}}$ & 0.0031 \\
\hline Arginine & $4.00 \pm 0.01^{\mathrm{a}}$ & $2.83 \pm 0.06^{\mathrm{b}}$ & 0.0001 \\
\hline Isoleucine & $3.01 \pm 0.02^{\mathrm{b}}$ & $3.99 \pm 0.02^{\mathrm{a}}$ & 0.0001 \\
\hline TEAA & $25.10 \pm 0.14^{\mathrm{b}}$ & $28.30 \pm 0.18^{\mathrm{a}}$ & 0.0001 \\
\hline
\end{tabular}

Means with different superscript differ significantly $(\mathrm{p}<00.05)$ 


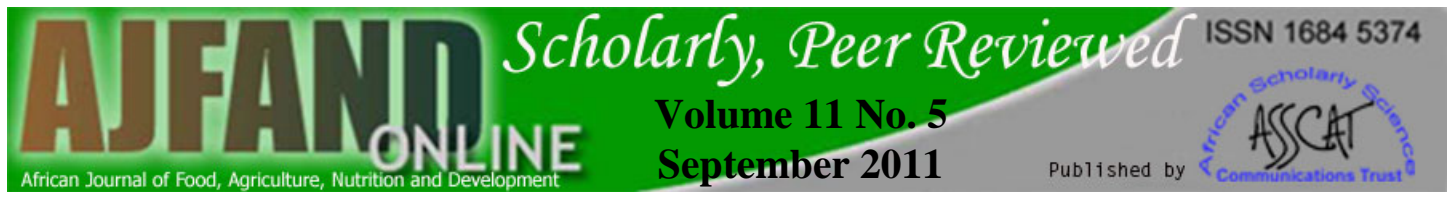

Table 5: Performance characteristics of broilers fed fermented cassava peel and caged layers' manure per bird per day

\begin{tabular}{|c|c|c|c|c|c|}
\hline \multirow{3}{*}{$\begin{array}{l}\text { Period/ Parameters } \\
\underline{\mathbf{0}-\mathbf{2 8} \mathbf{d}}\end{array}$} & \multirow{2}{*}{\multicolumn{3}{|c|}{ \% inclusion of FCPCLM }} & \multirow[b]{3}{*}{ SEM } & \multirow[b]{3}{*}{ P-value } \\
\hline & & & & & \\
\hline & \multicolumn{2}{|c|}{$0 \quad 25$} & 50 & & \\
\hline Feed intake g & $58.8^{b}$ & $68.5^{\mathrm{a}}$ & $71.5^{\mathrm{a}}$ & 2.88 & 0.0001 \\
\hline Live weight g & $868^{\mathrm{C}}$ & $980^{b}$ & $1036^{\mathrm{a}}$ & 126.3 & 0.0003 \\
\hline $\begin{array}{l}\text { Body weight gain } \\
\text { (g) }\end{array}$ & $31^{\mathrm{c}}$ & $35.1^{b}$ & $37.4^{\mathrm{a}}$ & 2.48 & 0.0001 \\
\hline $\begin{array}{l}\text { Feed conversion } \\
\text { ratio }\end{array}$ & $1.89^{\mathrm{a}}$ & $1.96^{b}$ & $1.93^{b}$ & 0.06 & 0.001 \\
\hline $\begin{array}{l}\text { Protein efficiency } \\
\text { ratio }\end{array}$ & 2.09 & 2.14 & 2.30 & 0.13 & 0.08 \\
\hline Feed cost/kg ( & $¥ 92.9$ & $\# 87.9$ & $\# 82.9$ & & \\
\hline $\begin{array}{l}\text { Cost/kg flesh } \\
\text { gained }(\mathrm{N})\end{array}$ & $\# 183.55^{\mathrm{a}}$ & $\sharp 172.21^{\mathrm{b}}$ & $\# 160.04^{\mathrm{c}}$ & 12.70 & 0.002 \\
\hline \multicolumn{6}{|l|}{$29-56 d$} \\
\hline$\overline{\text { Feed intake } g}$ & $111.01^{b}$ & $115.83^{\mathrm{a}}$ & $118.55^{\mathrm{a}}$ & 6.38 & 0.002 \\
\hline Live weight g & $1296.70^{\mathrm{C}}$ & $1361.03^{b}$ & $1495.50^{\mathrm{a}}$ & 26.3 & 0.003 \\
\hline $\begin{array}{l}\text { Body weight gain } \\
\text { (g) }\end{array}$ & $46.31^{\mathrm{c}}$ & $48.6^{\mathrm{b}}$ & $53.41^{\mathrm{a}}$ & 0.48 & 0.001 \\
\hline $\begin{array}{l}\text { Feed conversion } \\
\text { ratio }\end{array}$ & $2.39^{b}$ & $2.38^{b}$ & $2.21^{\mathrm{a}}$ & 0.16 & 0.001 \\
\hline $\begin{array}{l}\text { Protein efficiency } \\
\text { ratio }\end{array}$ & $2.10^{\mathrm{c}}$ & $2.13^{b}$ & $2.29^{a}$ & 0.13 & 0.0002 \\
\hline Feed cost/kg ( & $\$ 79.13$ & $¥ 75.13$ & $¥ 70.85$ & $\$ 79.13$ & \\
\hline $\begin{array}{l}\text { Cost/kg flesh } \\
\text { gained }(\mathrm{N})\end{array}$ & $\$ 189.74^{\mathrm{a}}$ & $\# 178.85^{\mathrm{b}}$ & $\$ 157.30^{\mathrm{C}}$ & 9.70 & 0.0002 \\
\hline \multicolumn{6}{|l|}{$0-56 d$} \\
\hline Feed intake g & $84.91^{\mathrm{c}}$ & $92.17^{b}$ & $95.03^{\mathrm{a}}$ & 1.56 & 0.0001 \\
\hline Live weight g & $1296.70^{\mathrm{C}}$ & $1361.03^{b}$ & $1495.50^{\mathrm{a}}$ & 26.3 & 0.003 \\
\hline $\begin{array}{l}\text { Body weight gain } \\
\text { (g) }\end{array}$ & $22.53^{b}$ & $23.68^{\mathrm{a}}$ & $26.08^{\mathrm{a}}$ & 1.67 & 0.0003 \\
\hline $\begin{array}{l}\text { Feed conversion } \\
\text { ratio }\end{array}$ & $3.77^{b}$ & $3.87^{b}$ & $3.64^{\mathrm{a}}$ & 0.03 & 0.0001 \\
\hline $\begin{array}{l}\text { Protein efficiency } \\
\text { ratio }\end{array}$ & $2.09^{b}$ & $2.14^{b}$ & $2.30^{\mathrm{a}}$ & 0.11 & 0.0001 \\
\hline
\end{tabular}

Means with different superscript differ significantly $(\mathrm{p}<00.05)$

As at the time of this experiment, 1US\$ = 145 


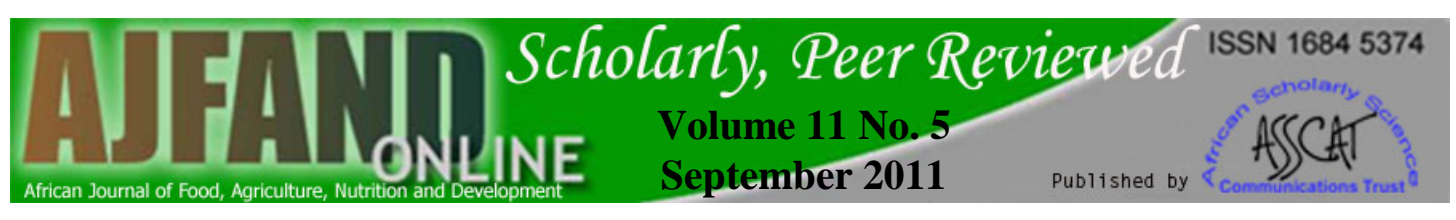

Table 6: Some serum proteins and enzymes of broilers fed fermented mixture of cassava peel and caged layers' manure

\begin{tabular}{|c|c|c|c|c|c|c|}
\hline \multirow[b]{2}{*}{ Parameters } & \multicolumn{4}{|c|}{ \% replacement of maize with FCPCLM } & \multirow[b]{2}{*}{ SEM } & \multirow[b]{2}{*}{ P-value } \\
\hline & & & & 50 & & \\
\hline $\begin{array}{l}\text { Total } \\
\text { protein } \\
\text { (g/dl) }\end{array}$ & 9.12 & 9.38 & 9.39 & 1.38 & & 0.07 \\
\hline $\begin{array}{l}\text { Albumin } \\
\text { (g/dl) }\end{array}$ & 1.06 & 1.28 & 1.21 & 1.95 & & 0.006 \\
\hline $\begin{array}{l}\text { Globulin } \\
\text { (g/dl) }\end{array}$ & 8.06 & 8.10 & 8.18 & 0.56 & & 0.03 \\
\hline *ALT (g/dl) & 15.3 & 21.0 & 17.0 & 1.05 & & 0.08 \\
\hline $\begin{array}{l}* * A S T \\
(\mathrm{~g} / \mathrm{dl})\end{array}$ & 3.69 & 2.44 & 2.31 & 3.49 & & 0.09 \\
\hline
\end{tabular}

*ALT = Alanine amino transaminase (EC 2.6.1.1.1)

**AST = Aspartate amino transaminase (EC 2.6.1.1.2) 


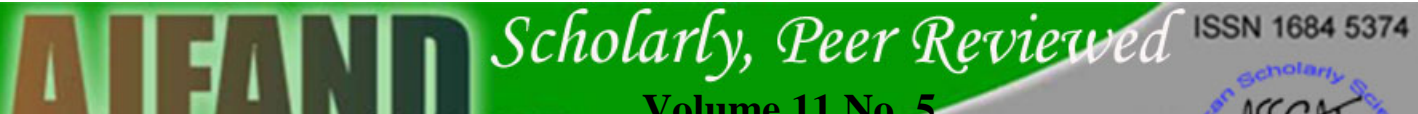 1. HIONLINE Volume 11 No.5 \\ September 2011

Table 7: Carcass and cut-parts of broiler starter chicks fed fermented mixture of cassava peel and caged layers' manure at 56 day of age

\begin{tabular}{|c|c|c|c|c|c|}
\hline \multicolumn{6}{|c|}{ \% replacement of maize with FCPCLM } \\
\hline Parameters & & & & SEM & P-value \\
\hline $\begin{array}{l}\text { Eviscerated } \\
\text { weight (\%) }\end{array}$ & $88.71^{b}$ & $90.35^{\mathrm{a}}$ & $93.7^{\mathrm{a}}$ & 3.96 & 0.002 \\
\hline Wing & $32.64^{b}$ & $38.20^{\mathrm{a}}$ & $38.15^{\mathrm{a}}$ & 3.06 & 0.001 \\
\hline Head & 34.74 & 34.83 & 34.88 & 0.34 & 0.067 \\
\hline Neck & 44.30 & 44.35 & 44.34 & 0.45 & 0.032 \\
\hline Breast & $53.33^{b}$ & $57.6^{\mathrm{a}}$ & $59.6^{\mathrm{a}}$ & 2.22 & 0.071 \\
\hline Back & 72.81 & 72.60 & 72.50 & 2.45 & 0.02 \\
\hline Drum stick & 94.72 & 95.34 & 95.66 & 1.15 & 0.087 \\
\hline Thigh & 42.51 & 41.89 & 42.01 & 1.16 & 0.03 \\
\hline $\begin{array}{l}\text { Whole } \\
\text { intestine } \\
(\mathrm{cm})\end{array}$ & 223 & 225 & 227 & 2.22 & 0.026 \\
\hline $\begin{array}{l}\text { Small } \\
\text { intestine } \\
(\mathrm{cm})\end{array}$ & 193 & 194 & 193 & 1.89 & 0.082 \\
\hline $\begin{array}{l}\text { Large } \\
\text { intestine } \\
(\mathrm{cm})\end{array}$ & $2.28^{b}$ & $4.36^{\mathrm{a}}$ & $4.40^{\mathrm{a}}$ & 0.44 & 0.001 \\
\hline
\end{tabular}

Means with different superscript differ significantly $(\mathrm{p}<00.05)$ 


\section{REFERENCES}

1. John MJ Alternative approaches to adoption of animal technology: In Proc. World Food conference IOWA State University, Ames, IOWA,1976; Pp 581 592.

2. Dairo FAS, Ogunmodede BK, Ohikhuare GO and O Oteniya Determination of energy values of locally produced palm kernel and Coconut meal in growing poultry chicks.Trop. J. Anim. Sc. 2001; 4(2):75-83.

3. Balagopalan C Cassava utilization in food, feed and industry, In: Hillock, R.J. Thresh, J. M. and Bellotti, A.C. (Eds) Cassava: Biology production and utilization, 2002 pp 301 - 318 (Kerala, India).

4. Eruvbetine D, Tajudeen ID, Adeosun AT and AA Oloyede Cassava (Manihot esculanta) leaf and tuber concentrate in diets for broiler chickens. Bioresource Technology 2003;86: 277 - 281.

5. Onyimonyi AE and SO C Ugwu Bioeconomic indices of broiler chicks fed varying ratios of cassava peel/bovine blood. Int'l. J. Poult. Sc. 2007;6 (5): 318-321.

6. Aina ABJ Replacing maize with cassava peel in finisher ration for cockerels: the effects on cut up pieces of eviscerated carcass. Nig. J. Anim. Prod. 1990; 17: $17-22$.

7. Osei SA and S Duodu Effect of fermented cassava peel meal on the performance of broiler. British Poult. Sc. 1988; 29 (3): 671 - 675.

8. Rankins DL, Eason JT and AH McCaskey Nutritional and toxicological evaluations of three deep stacking methods for the processing of broiler litter as a foodstuff for beef cattle. Animal Production 1993; 56: 321-326.

9. Bagley CP, Evans RR and WB Burdine Broiler litter as a fertilizer or livestock feed. Journal of Production Agriculture (USA) 1996; 9: 342-346.

10. AOAC. Official Method of Analysis, 18th ed., Association of Official Analytical Chemist, Washington DC, 2005.

11. Pauzenga U Feeding parent stock. Zootechnica International, 1985; December. Pp $22-24$.

12. Rehinhold JG Manual determination of total serum proteins, albumin and Globulin fraction by biuret method In: Standard Methods of Clinical Chemistry. 1953.

13. Doumas BT and NG Briggs Serum albumin by bromocresol green binding. Stand. Methods Clin. Chem. 1972; 7: 175 - 179. 
14. Rodkey FL Separation and determination of the total globulins of human serum. Clin. Chem. 1965; 11:488-494.

15. Reitman S and S Frankel A colorimetric method for the determination of Serum glutamate pyruvate transaminase and serum glutamate oxaloacetate transaminase. Am. J. Clin. Path. 1957; 28: 56-62.

16. Fawole MO and BA Oso Laboratory manual of microbiology.Spectrum Books Limited 1995; Pp $74-76$.

17. SAS SAS/STASt. Guide for personal computers. Version 6. Ed. 1987: Pp 697- 978.

18. Sniffen CJ Rumen microbial ecology. In: Biotechnology in the Feed Industry, Alltech Technical Publication 1987.

19. El Jalil MH, Faid $\mathbf{M}$ and $\mathbf{M}$ Elyachioui A biotechnological process for treatment and recycling poultry wastes manure as a feed ingredient. Biomass and Bioenergy 2001; 21(4): 301 - 309.

20. Adeyemi OA and FO Familade Replacement of maize by rumen filtrate fermented corn-cob in layer diets. Bioresource Technol. 2003; 90 (2): 221224.

21. Osei SA Sun-dried cassava peel meal as feed ingredient in broiler diets. Tropical Agriculture 1992; 69:273 - 275. 